\title{
Synthesis of high-silica ZSM-5 with seeds in the presence of ethanol and amine
}

\author{
(Síntese da ZSM-5 de alto teor de sílica com sementes \\ na presença de etanol e aminas)
}

\author{
T. R. D. Mendonça ${ }^{1 *}$, J. R. Santos ${ }^{1}$, L. R. A. Sarmento ${ }^{1}$, D. C. M. Silva ${ }^{1}$, O. M. S. Cysneiros ${ }^{1}$, A. O. S. Silva \\ ${ }^{1}$ Federal University of Alagoas, Laboratory of Catalyst Synthesis, 57072-900, Maceió, AL, Brazil
}

\begin{abstract}
The possibility of crystallization of ZSM-5 with high Si/Al ratio was evaluated through the combined use of crystallization seeds and organic compounds that are not conventional directing agents for ZSM-5 (ethanol, methylamine, ethylamine, propylamine, butylamine, isopropylamine and diethylamine) in order to find a less toxic and costly route of synthesis. In addition, the influence of the stirring during the crystallization step on the properties of the ZSM-5 obtained in these synthesis conditions was verified. The obtained zeolites were analyzed by X-ray diffractometry in order to understand the effects of the templates. The analyses of $\mathrm{NH}_{3}$-TPD, nitrogen adsorption, SEM, and TG/DTA were performed for the samples with better crystallinity. The procedure was successfully employed for the synthesis of MFI samples using propylamine as an alternative structure-directing agent. Its mean crystallite size ranged from 23 to $24 \mathrm{~nm}$ and was efficient in the cracking reaction of $\mathrm{n}$-hexane.
\end{abstract}

Keywords: ZSM-5, seed crystals, high silica, amines, ethanol.

Resumo

A possibilidade de cristalização da ZSM-5 com alta razão Si/Al foi avaliada através do uso combinado de sementes de cristalização e compostos orgânicos que não são direcionadores convencionais da ZSM-5 (etanol, metilamina, etilamina, propilamina, butilamina, isopropilamina e dietilamina) a fim de encontrar uma rota de síntese menos tóxica e cara. Adicionalmente foi verificada a influência da agitação durante a etapa de cristalização sobre as propriedades da ZSM-5 obtida nessas condições de síntese. As zeólitas obtidas foram analisadas por difratometria de raios $\mathrm{X}$ para entender os efeitos dos direcionadores. As análises de $\mathrm{NH}_{3}-\mathrm{TPD}$, adsorção de nitrogênio, MEV e TG/DTA foram realizadas para as amostras com melhor cristalinidade. O procedimento foi empregado com sucesso para a síntese de amostras de MFI usando propilamina como agente direcionador de estrutura alternativo. Seu tamanho médio de cristalito variou de 23 a 24 nm e foi eficiente na reação de craqueamento do n-hexano.

Palavras-chave: ZSM-5, cristais sementes, alta sílica, aminas, etanol.

\section{INTRODUCTION}

ZSM-5 is a zeolite of the pentasil family, whose porous structure is based on three-dimensional $\mathrm{SiO}_{4}$ and $\mathrm{AlO}_{4}$ networks [1]. Its structure is composed of two channels systems with an aperture formed by ten member-interlocking rings. Due to the diameter and shape of the channels, the ZSM-5 is distinguished by its shape selectivity that allows its use as a catalyst in several important industrial processes [2], such as isomerization of xylenes [3], disproportion of toluene, alkylation of toluene with methanol, alkylation of benzene with ethylene [4], and conversion of alcohols to light olefins, mainly ethene and propene $[5,6]$. The quaternary ammonium cation, tetrapropylammonium, is the main compound used to obtain the crystalline structure of ZSM-5 zeolite according to the original Mobil Oil Co. procedure [7],

*thay.dantas@hotmail.com

(D) https://orcid.org/0000-0002-7213-4177 however, this molecule is costly and presents considerable toxicity. For this reason, several studies have investigated substitutes to this compound. Lok et al. [8] have shown that quaternary ammonium compounds are not essentials for the crystallization of ZSM-5 zeolite. Some studies indicate that the ZSM-5 can be obtained in the presence of aliphatic amines [9], diamines [10-12], alkanolamines [13], glycerol [14], dodecylbenzenesulfonate [15], aliphatic alcohols and ammonia [16]. In order to replace part of these high-cost organic nitrogen compounds, or even to suppress their use, some studies have evaluated the use of co-directing agents and seed crystals [17]. The co-directing agents employed are generally low molecular weight alcohols, such as ethanol or simple (low-carbon) amines. These are used together with a structure-directing agent with the purpose of reducing the amount of expensive nitrogen compounds employed in the synthesis and improving the final properties of the zeolite [18]. The use of seeds consists in adding to the reaction mixture crystals of ZSM-5 previously synthesized or zeolite crystals with similar structures, such as silicalite. The use 
of seeds in the synthesis without the addition of structuredirecting agents inhibits the formation of defects and impurities and reduces the crystallization time [19]. The final properties of the zeolite formed may be improved with the addition in different concentration of seed crystals obtained and/or activated by various processes. The seeds can be formed by crystals of different sizes and morphologies [20] and can be combined with an alternative structure-directing agent [18].

ZSM-5 with high silica content was recognized to be advantageous because it presents a lower acidity level, which in many catalytic reactions could reduce the tendency for coke deposition, which typically occurs in this type of material [21]. Zeolites with high silica content are generally prepared from reaction mixtures containing quaternary ammonium cations. The use of these compounds, which are used as structure-directing agents (SDA) and charge balancing cations, increasing the cost of synthesis of the final catalyst, in addition to presenting a certain level of toxicity [19]. The addition of crystals seeds is an easy and efficient practice to control the formation of a certain zeolitic phase, in addition to reducing the time of synthesis. However, Mendonça [22], Lowe et al. [23], and Wu et al. [24] reported that they did not succeed in the synthesis of high silica ZSM-5 zeolite by the seed-induced method, without the addition of conventional organic directing agents, due to the appearance of competitive phases. Only from reaction mixtures with $\mathrm{SiO}_{2} / \mathrm{Al}_{2} \mathrm{O}_{3}$ ratio of 50 , it was possible to obtain ZSM-5 zeolite samples with high crystallinity (close to 100\%) [22]. Samples synthesized with reactional mixtures of $S A R=100$ resulted in materials with low MFI phase crystallinity due to the appearance of the concurrent cristobalite phase [22]. Narayanan et al. [25] found that the synthesis of ZSM-5 zeolite from gels without the addition of SDA with $\mathrm{SiO}_{2} / \mathrm{Al}_{2} \mathrm{O}_{3}$ ratio greater than 50 produces large amounts of the condensed $\alpha$-quartz phase together with the ZSM-5. In this system, a progressive reduction of the specific surface area with the increase of the SAR was also observed, probably due to increased contamination with $\alpha$-quartz.

The synthesis of ZSM-5 has been studied with the application of different amines instead of TPAOH or TPABr used as SDA in conventional methods [26]. The organic amines appear to provide a tetrahedral coordination environment, directly providing centers capable of directing the crystallization of the zeolitic phase; this accelerates crystallization in contrast to other systems. This approach allows the synthesis of the high-crystallinity ZSM-5 zeolite with different structure-directing agents, carefully controlling the synthesis conditions [27]. The present study reports the crystallization of the ZSM-5 zeolite with high $\mathrm{SiO}_{2} / \mathrm{Al}_{2} \mathrm{O}_{3}$ ratios using crystallization seeds under static and agitated conditions, varying the synthesis parameters such as time, organic/ $\mathrm{SiO}_{2}$ and $\mathrm{OH} / \mathrm{SiO}_{2}$ ratios, using different amines and ethanol as alternative structure-directing agents.

\section{EXPERIMENTAL}

Reagents: the samples were synthesized from gel compositions described in the second column of Tables I and II. The following reagents were used as sources of inorganic materials: sodium silicate $\left(27.64 \% \mathrm{SiO}_{2}\right.$ and $7.86 \% \mathrm{Na}_{2} \mathrm{O}$, Quimesp), aluminum sulfate $\left(17.15 \% \mathrm{Al}_{2} \mathrm{O}_{3}\right.$, $\mathrm{Al}_{2}\left(\mathrm{SO}_{4}\right)_{3} \cdot 18 \mathrm{H}_{2} \mathrm{O}$, Merck) and sulfuric acid $(98 \%$, SigmaAldrich). The alternative SDA evaluated were: ethanol ETH (99.5\%, Sigma-Aldrich), methylamine - MET (40\%, Sigma-Aldrich), ethylamine - ETI (69.5\%, Sigma-Aldrich),

Table I - Main parameters used in the synthesis of ZSM-5 under static conditions.

[Tabela I - Principais parâmetros utilizados nas sínteses de ZSM-5 em condições estáticas.]

\begin{tabular}{|c|c|c|c|c|c|}
\hline Sample & $\begin{array}{l}\text { Gel composition (molar base) } \\
\mathrm{Al}_{2} \mathrm{O}_{3}: \mathrm{SiO}_{2}: \mathrm{Na}_{2} \mathrm{O}: \mathrm{H}_{2} \mathrm{SO}_{4}: \mathrm{H}_{2} \mathrm{O}\end{array}$ & $\begin{array}{l}\text { Alternative } \\
\text { SDA }^{a}\end{array}$ & $\begin{array}{l}\mathrm{SDA} / \mathrm{SiO}_{2} \\
\text { molar ratio }\end{array}$ & $\begin{array}{l}\mathrm{OH} / \mathrm{SiO}_{2} \\
\text { molar ratio }\end{array}$ & $\begin{array}{c}\text { Time } \\
\text { (h) }\end{array}$ \\
\hline $\mathrm{Z} 2$ & $1.0: 150: 51.70: 40.45: 3000$ & ETH & 1.0 & 0.15 & 15 \\
\hline $\mathrm{Z3}$ & $1.0: 150: 51.70: 40.45: 3000$ & ETH & 3.0 & 0.15 & 21 \\
\hline $\mathrm{Z} 4$ & $1.0: 150: 51.70: 36.70: 3000$ & ETH & 1.5 & 0.2 & 21 \\
\hline $\mathrm{Z} 5$ & $1.0: 150: 51.70: 36.70: 3000$ & ETH & 3.0 & 0.2 & 21 \\
\hline Z6 & $1.0: 150: 48.42: 33.42: 3000$ & MET & 0.1 & 0.2 & 21 \\
\hline $\mathrm{Z7}$ & $1.0: 150: 48.42: 33.42: 3000$ & IPA & 0.1 & 0.2 & 21 \\
\hline $\mathrm{Z} 8$ & $1.0: 150: 48.42: 33.42: 3000$ & BUT & 0.1 & 0.2 & 24 \\
\hline Z9 & $1.0: 150: 48.42: 33.42: 3000$ & PRO & 0.1 & 0.2 & 18 \\
\hline $\mathrm{Z} 10$ & $1.0: 150: 48,42: 33,42: 3000$ & ETI & 0.1 & 0.2 & 21 \\
\hline Z11 & $1.0: 150: 48.42: 33.42: 3000$ & DIE & 0.1 & 0.2 & 18 \\
\hline $\mathrm{Z} 12$ & $1.0: 150: 48.42: 40.92: 3000$ & PRO & 0.1 & 0.1 & 21 \\
\hline Z13 & $1.0: 150: 48.42: 40.92: 3000$ & PRO+ETH & $0.1+0.5$ & 0.1 & 18 \\
\hline Z14 & $1.0: 150: 48.42: 40.92: 3000$ & PRO & 0.2 & 0.1 & 21 \\
\hline
\end{tabular}

${ }^{a}$ ETH-ethanol, MET-methylamine, IPA-isopropylamine, BUT-buthylamine, PRO-propylamine, ETI-ethylamine, DIE-diethylamine. 
Table II - Main parameters used in ZSM-5 synthesis with stirring during crystallization.

[Tabela II - Principais parâmetros utilizados nas sínteses de ZSM-5 com agitação durante a cristalização.]

\begin{tabular}{cccccc}
\hline Sample & $\begin{array}{c}\mathrm{Gel} \mathrm{composition} \mathrm{(molar} \mathrm{base)} \\
\mathrm{Al}_{2} \mathrm{O}_{3}: \mathrm{SiO}_{2}: \mathrm{Na}_{2} \mathrm{O}: \mathrm{H}_{2} \mathrm{SO}_{4}: \mathrm{H}_{2} \mathrm{O}\end{array}$ & $\begin{array}{c}\text { Alternative } \\
\mathrm{SDA}^{\mathrm{a}}\end{array}$ & $\begin{array}{c}\mathrm{SDA} / \mathrm{SiO}_{2} \\
\text { molar ratio }\end{array}$ & $\begin{array}{c}\mathrm{OH} / \mathrm{SiO}_{2} \\
\text { molar ratio }\end{array}$ & $\begin{array}{c}\text { Time } \\
(\mathrm{h})\end{array}$ \\
\hline Z3-S & $1.0: 150: 51.70: 40.45: 3000$ & $\mathrm{ETH}$ & 3.0 & 0.15 & 21 \\
Z5-S & $1.0: 150: 51.70: 36.70: 3000$ & ETH & 3.0 & 0.2 & 21 \\
Z9-S & $1.0: 150: 48.42: 33.42: 3000$ & PRO & 0.1 & 0.2 & 18 \\
Z12-S & $1.0: 150: 48.42: 40.92: 3000$ & PRO & 0.1 & 0.1 & 21 \\
Z13-S & $1.0: 150: 48.42: 40.92: 3000$ & PRO+ETH & $0.1+0.5$ & 0.1 & 18 \\
Z14-S & $1.0: 150: 48.42: 40.92: 3000$ & PRO & 0.2 & 0.1 & 21 \\
\hline${ }_{\text {Alternative SDA employed in the synthesis as specified in Table I. }}$ & & & &
\end{tabular}

propylamine - PRO (99\%, Fluka), butylamine - BUT (99.5\%, Sigma-Aldrich), isopropylamine - IPA (99.5\%, SigmaAldrich), and diethylamine - DIE (99.5\%, Sigma-Aldrich). A commercial ZSM-5 sample (Zeolyst, CBV 2314) was used as a source of seed crystals (in the concentration of $10 \% \mathrm{w} / \mathrm{w}$ of seed crystals in relation to the amount of silica used in the gel).

Synthesis: the mixtures were performed according to the following procedure: $\mathrm{H}_{2} \mathrm{SO}_{4}$ was added to $40 \%$ of $\mathrm{H}_{2} \mathrm{O}$ (solution $\mathrm{A}$ ), $\mathrm{Al}_{2}\left(\mathrm{SO}_{4}\right)_{3} .18 \mathrm{H}_{2} \mathrm{O}$ was dissolved in $50 \%$ of $\mathrm{H}_{2} \mathrm{O}$ (solution $\mathrm{B}$ ), and solution $\mathrm{A}$ was added to solution $\mathrm{B}$ (resulting in solution $\mathrm{C}$ ). Sodium silicate was added to solution $\mathrm{C}$ under stirring (to obtain solution D). Structuredirecting agents were added to solution $\mathrm{D}$, the mixture stirred for $40 \mathrm{~min}$ and, in the last step, the seed crystals dispensed in $10 \%$ of water was added. The gel was kept under stirring until its complete homogenization (approximately $10 \mathrm{~min}$ ). Then it was transferred to $70 \mathrm{~mL}$ stainless steel autoclave lined with polytetrafluoroethylene (PTFE) and heated at 170 ${ }^{\circ} \mathrm{C}$ for 15 to $24 \mathrm{~h}$. For comparison, the best samples obtained in static conditions (Table II) were synthesized under agitated conditions in a furnace (Tecnal, TE-028) capable of rotating the autoclaves at $60 \mathrm{rpm}$. The other parameters of synthesis were identical to those used in experiments under static conditions. The obtained products were washed with distilled water until it reached neutral $\mathrm{pH}$ and the solids were separated by vacuum filtration and dried in an oven for $24 \mathrm{~h}$ at $100{ }^{\circ} \mathrm{C}$. The samples were calcined at $550{ }^{\circ} \mathrm{C}$ with a heating rate of $2{ }^{\circ} \mathrm{C} \cdot \mathrm{min}^{-1}$ for $6 \mathrm{~h}$, under an air flow of $100 \mathrm{~mL} \cdot \mathrm{min}^{-1}$. The ion exchange was performed twice with solution $0.5 \mathrm{M}$ of $\mathrm{NH}_{4} \mathrm{NO}_{3}\left(98 \%\right.$, Sigma-Aldrich) at $80{ }^{\circ} \mathrm{C}$ for $1 \mathrm{~h}$. The solids were centrifuged and washed to neutral $\mathrm{pH}$, oven dried at $100{ }^{\circ} \mathrm{C}$ for $24 \mathrm{~h}$, and then calcined under air flow $\left(100 \mathrm{~mL} \cdot \mathrm{min}^{-1}\right)$ using a heating rate of $2{ }^{\circ} \mathrm{C} \cdot \mathrm{min}^{-1}$ up to $550{ }^{\circ} \mathrm{C}$ for $3 \mathrm{~h}$.

Characterizations: the analysis of X-ray diffraction (XRD) were performed using a Shimadzu XRD-6000 diffractometer with Ni-filtered and monochromatic radiation $\mathrm{CuK} \alpha(\lambda=0.1542 \mathrm{~nm}$, voltage $=40 \mathrm{kV}$, current $=30 \mathrm{~mA})$. The relative crystallinity of the synthesized samples was calculated according to [28], using areas of the diffraction peaks located in the $2 \theta$ range between $22^{\circ}$ and $25^{\circ}$, comparing the peak areas of a standard sample (which was assumed to be $100 \%$ crystalline). The mean crystallite diameter was estimated by the Scherrer equation [29] using the main diffraction peaks of the ZSM-5 phase. Nitrogen adsorption at $-196{ }^{\circ} \mathrm{C}$ was performed on a Micromeritics ASAP 2020 instrument in the $\mathrm{P} / \mathrm{P}_{0}$ interval between 0.04 and 0.99 . The samples were treated at $350{ }^{\circ} \mathrm{C}$ for $24 \mathrm{~h}$ prior to nitrogen adsorption. The specific surface area $\left(\mathrm{S}_{\mathrm{BET}}\right)$ was calculated by the BET method, and the external area $\left(\mathrm{S}_{\mathrm{E}}\right)$, microporous area $\left(\mathrm{S}_{\mathrm{Mic}}\right)$, total volume $\left(\mathrm{V}_{\mathrm{T}}\right)$, and microporous volume $\left(\mathrm{V}_{\mathrm{Mic}}\right)$ were obtained by the t-plot method. The acidity of the samples was measured by $\mathrm{NH}_{3}$-TPD using a Termolab multipurpose analytical system (SAMP3). The samples were treated at $500{ }^{\circ} \mathrm{C}$ in a helium flow of $30 \mathrm{~mL} \cdot \mathrm{min}^{-1}$ for $1 \mathrm{~h}$, then cooled to $100{ }^{\circ} \mathrm{C}$ and submitted to adsorption of ammonia until saturation of the acid sites. The desorption was carried out in the range of 100 to $800{ }^{\circ} \mathrm{C}$ at $10^{\circ} \mathrm{C} \cdot \mathrm{min}^{-1}$. The samples of zeolites formed were submitted to chemical analysis in a Shimadzu EDX-7000 energy dispersive X-ray fluorescence spectrometer to determine the $\mathrm{SiO}_{2} / \mathrm{Al}_{2} \mathrm{O}_{3}$ ratio. The size and particle morphology of the samples were observed by scanning electron microscopy (SEM) in a Hitachi S-3400N microscope. The thermal stability of the materials was studied through the thermal decomposition curves obtained in a thermobalance Shimadzu DTG-60H. The samples were heated at a rate of $10{ }^{\circ} \mathrm{C} \cdot \mathrm{min}^{-1}$, starting at room temperature up to $800{ }^{\circ} \mathrm{C}$, under a dynamic synthetic air atmosphere with a flow rate of $50 \mathrm{~mL} \cdot \mathrm{min}^{-1}$.

Catalytic test: the cracking tests of n-hexane $(99 \%$, Sigma-Aldrich) were performed in a fixed bed tubular quartz microreactor $(3.17 \mathrm{~mm}$ i.d.) in a TCAT-3 catalytic titration unit, Termolab. $100 \mathrm{mg}$ of zeolite supported on $200 \mathrm{mg}$ of quartz wool, at $550{ }^{\circ} \mathrm{C}$, atmospheric pressure and space-time of $0.54 \mathrm{~h}$ were used. The products were analyzed on a Shimadzu GC-2014 chromatograph with $\mathrm{Na}_{2} \mathrm{SO}_{4} / \mathrm{Al}_{2} \mathrm{O}_{3}$ capillary column $(0.53 \mathrm{~mm}$ in diameter and $30 \mathrm{~m}$ in length).

\section{RESULTS AND DISCUSSION}

Physicochemical property: Fig. 1 shows the X-ray diffraction profiles of the synthesized samples with high relative crystallinity. Table III shows the phase identification of statically synthesized samples. The obtained phases, ZSM-5 and magadiite, exhibited identical patterns to the 
standards 42-0023 and 42-1350, respectively, of the Joint Committee on Powder Diffraction Standards (JCPDS). Only the sample Z2 presented the characteristic peaks of ZSM-5 with no other observed peak, indicating high purity (Fig. 1a). When the amount of ethanol and the $\mathrm{OH} / \mathrm{SiO}_{2}$ ratio was increased, ZSM-5 formation was observed along with a magadiite lamellar phase, indicating that the amount of ethanol was one of the parameters that controlled the formation of ZSM-5. Martens and Jacobs [30] have suggested that alcohols serve as pore-filling agents and
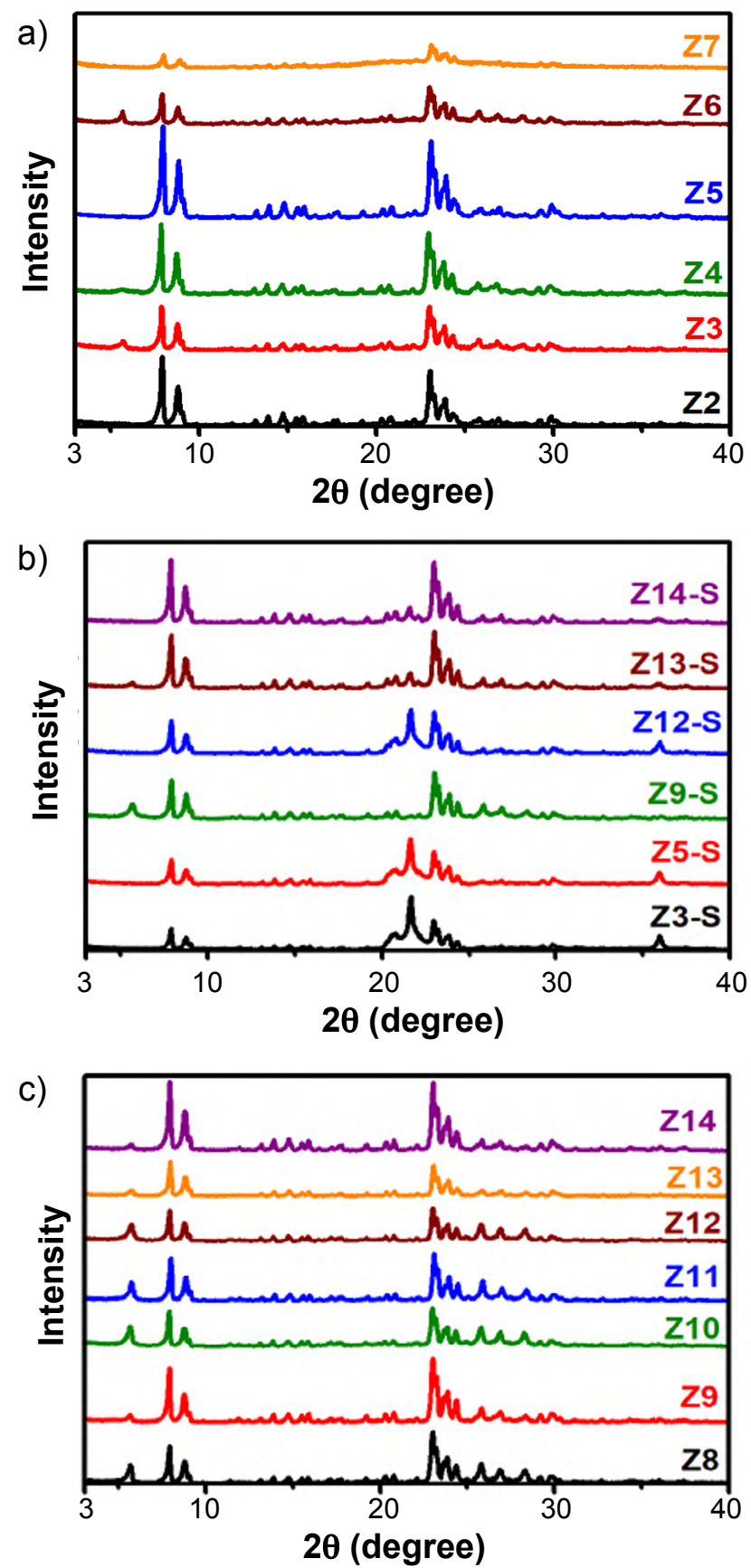

Figure 1: X-ray diffraction profiles of the synthesized samples under: a,b) static conditions; and c) stirring.

[Figura 1: Perfis de difração de raios $X$ das amostras sintetizadas: $a, b)$ em condições estáticas; e c) sob agitação.]
Table III - Solid yield, mean crystallite size, relative crystallinity and phase distribution for samples synthesized under static conditions.

[Tabela III - Rendimento em sólidos, tamanho médio de cristalito, cristalinidade relativa e distribuição de fases para amostras sintetizadas em condições estáticas.]

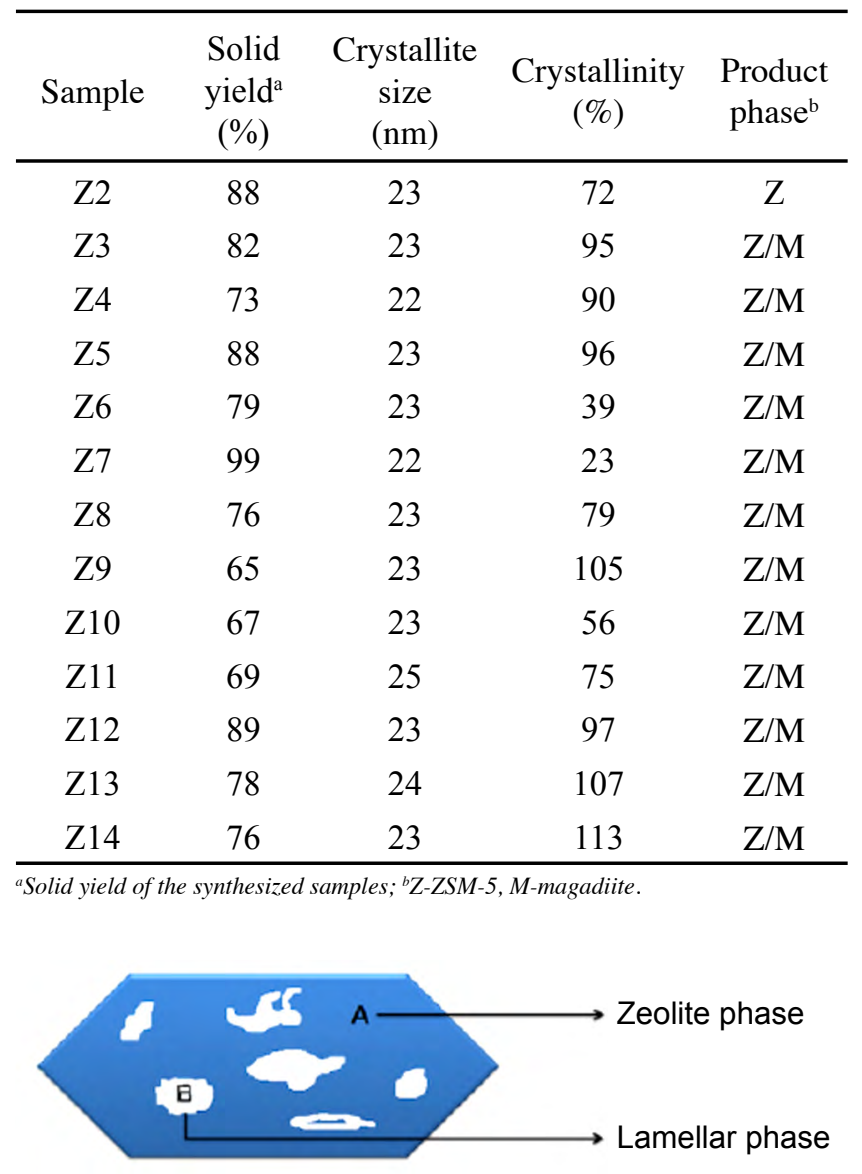

Figure 2: Proposed schematic diagram for the formation of ZSM5-magadiite composites.

[Figura 2: Diagrama esquemático proposto para a formação de compósitos de ZSM-5-magadiita.]

therefore do not have a directing function as well as primary amines. In all the samples synthesized with the addition of amines, the ZSM-5 and magadiite phases were obtained. The mechanism for the formation of the ZSM-5/magadiite compounds is not fully understood, as it is not necessary to use any SDA to obtain magadiite. Several studies report the synthesis of magadiite, where the ratio $\mathrm{SiO}_{2}: \mathrm{NaOH}$ has been in the range of 1:0.2 to 1:9 [31-36]. The ratio of $\mathrm{SiO}_{2}: \mathrm{NaOH}$ used in the experiments was from 1:0.32 to $1: 0.34$, whereby the amount of $\mathrm{NaOH}$ used in the syntheses favored the formation of magadiite, leading to the formation of several segregated areas classified in zeolitic and lamellar regions, as illustrated in Fig. 2. The zeolite regions contained $\mathrm{Na}_{2} \mathrm{O}, \mathrm{H}_{2} \mathrm{O}$, SDA and aluminosilicate species, resulting in the formation of ZSM-5. Meanwhile, the lamellar regions contained $\mathrm{Na}_{2} \mathrm{O}, \mathrm{H}_{2} \mathrm{O}$, ethanol (when appropriate) and highly silicic aluminosilicate species, which were hydrolyzed to form the magadiite phase. In addition, the concentration of 
$\mathrm{Na}_{2} \mathrm{O}$ species in the lamellar region needed to be higher than in the zeolite region to induce the hydrolysis of highly silicic aluminosilicate species to magadiite [37].

From the most crystalline samples, the syntheses thereof were carried out under agitation. Table IV shows the phase identification of these samples. The ZSM-5, magadiite and cristobalite phases exhibited identical patterns to those of the JCPDS files 42-0023, 42-1350 and 24-0689, respectively. The sample Z9-S had only the phases ZSM5/magadiite, the sample Z13-S presented the phases ZSM$5 /$ magadiite/cristobalite and all other samples presented ZSM-5/cristobalite (Fig. 1c). The formation of cristobalite may possibly be attributed to agitation in conjunction with extended times of synthesis and can be controlled by adjusting its conditions. It is suggested that the degradation of the ZSM-5 crystal lattice is not associated with the
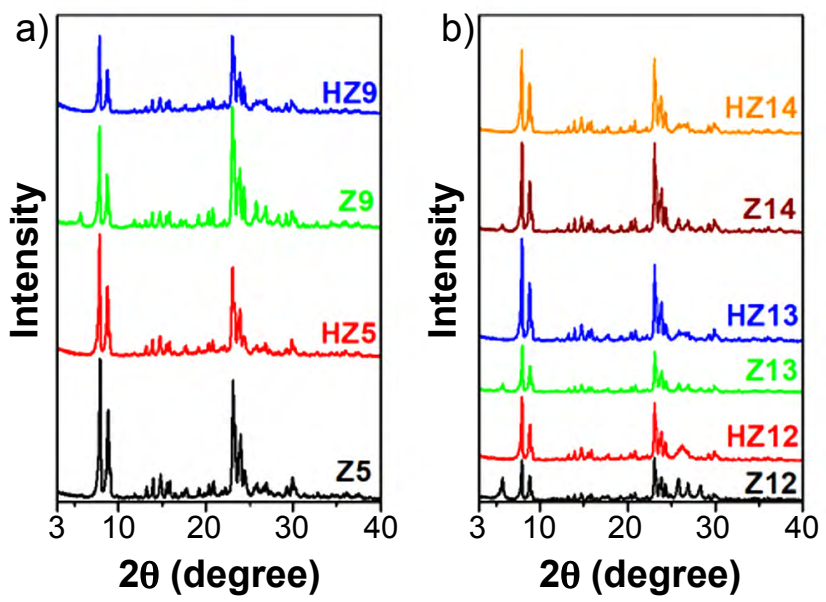

Figure 3: X-ray diffraction profiles of the samples with higher relative crystallinity, in the non-calcined form $(Z)$ and after calcination and ion exchange (HZ).

[Figura 3: Perfis de difração de raios $X$ das amostras com maiores cristalinidades relativas, na forma não calcinada (Z) e após calcinação e troca iônica (HZ).]

Table IV - Solid yield, mean crystallite size, relative crystallinity and phase distribution for samples synthesized under stirring.

[Tabela IV - Rendimento em sólidos, tamanho médio de cristalito, cristalinidade relativa e distribuição de fases para amostras sintetizadas sob agitação.]

\begin{tabular}{|c|c|c|c|c|}
\hline Sample & $\begin{array}{c}\text { Solid } \\
\text { yield }^{a} \\
(\%)\end{array}$ & $\begin{array}{c}\text { Crystallite } \\
\text { size } \\
(\mathrm{nm})\end{array}$ & $\begin{array}{c}\text { Crystallinity } \\
(\%)\end{array}$ & $\begin{array}{c}\text { Product } \\
\text { phase }^{\mathrm{b}}\end{array}$ \\
\hline Z3-S & 87 & 22 & 8 & $\mathrm{Z} / \mathrm{C}$ \\
\hline Z5-S & 71 & 21 & 32 & $\mathrm{Z} / \mathrm{C}$ \\
\hline Z9-S & 77 & 17 & 62 & $\mathrm{Z} / \mathrm{M}$ \\
\hline Z12-S & 85 & 20 & 36 & $\mathrm{Z} / \mathrm{C}$ \\
\hline Z13-S & 89 & 17 & 78 & $\mathrm{Z} / \mathrm{M} / \mathrm{C}$ \\
\hline Z14-S & 86 & 17 & 85 & $\mathrm{Z} / \mathrm{C}$ \\
\hline
\end{tabular}

primary conversion of ZSM-5 to cristobalite. Rather, the ZSM-5 lattice in the crystallization is broken initially leading to the accumulation of an amorphous product that is subsequently converted to cristobalite at higher temperatures [38]. In view of the obtained results of crystallinity, the best samples were submitted to calcination and subsequent ion exchange. Through the XRD patterns (Fig. 3) there was a complete disappearance of the magadiite lamellar phase after calcination and ion exchange. A possible explanation for the magadiite phase decomposition after calcination may be due to the reconfiguration of the lamellar plates in linear chains after the removal of the SDA, the zig-zag channels being reconstructed by connecting linear channels, thus obtaining the pure MFI structure [39].

The adsorption-desorption isotherms of $\mathrm{N}_{2}$ and the pore size distribution profiles by BJH are shown in Fig. 4 . Samples Z12 and Z14 showed isothermal profiles of type I, and samples Z5, Z9 and Z13 demonstrated a combination of two types I and IV, which are characteristics of microporous and mesoporous materials, respectively, according to the IUPAC classification. The strong adsorption in the region of low relative pressure $\left(\mathrm{P} / \mathrm{P}_{0}<0.1\right)$ is a typical characteristic of microporous materials. The hysteresis loop that appeared in the desorption isotherms in the range of relative pressures of $\mathrm{P} / \mathrm{P}_{0}>0.45$ is usually associated with the capillary condensation occurring in the mesopores. The shape of the hysteresis loop was similar to type $\mathrm{H} 4$, which indicated the presence of slit-like pores; in another interpretation, type $\mathrm{H} 4$ may evidence the presence of large mesopores introduced into a microporous matrix. Samples Z5 and Z9 presented the highest amount of nitrogen adsorption, whereas the rest of the samples presented lower adsorptions at high relative pressures, suggesting that these materials had an open surface with trimodal porosity that allowed continuous capture and formation of multiple layers of adsorbate with the increase of $\mathrm{P} / \mathrm{P}_{0}$ [40]. According to the pore size distribution by the $\mathrm{BJH}$ method using the adsorption isotherm, samples Z5, Z9 and Z13 exhibited a bimodal porosity, in the range of 0 to $50 \mathrm{~nm}$, with the presence of microporous (below $2 \mathrm{~nm}$ ) and mesoporous (between 2 and $50 \mathrm{~nm}$ ). Also due to the smooth slope of the isotherms in the range of relative pressure $\mathrm{P} / \mathrm{P}_{0}>0.45$, it may be due to the formation of nanocrystallite aggregates, which generate intercrystalline mesoporosity. However, samples Z12 and Z14 indicated predominantly microporous materials.

The textural properties of the ZSM-5 samples were measured using the $\mathrm{N}_{2}$ adsorption data by the BET, t-plot and BJH methods. As can be seen in Table V, the products of ethanol-synthesized systems presented lower values of the specific surface area, as well as a low degree of crystallinity. This can be attributed to the physicochemical properties of ethanol, which did not provide a tetrahedral center suitable for the organization of silica and alumina precursor compounds during crystallization, nor did it influence the $\mathrm{pH}$ of the gel [27], thus requiring a greater amount of structuredirecting agent. According to Uguina et al. [41], ZSM-5 does not crystallize in the presence of ethanol at high $\mathrm{SiO}_{2} / \mathrm{Al}_{2} \mathrm{O}_{3}$ 

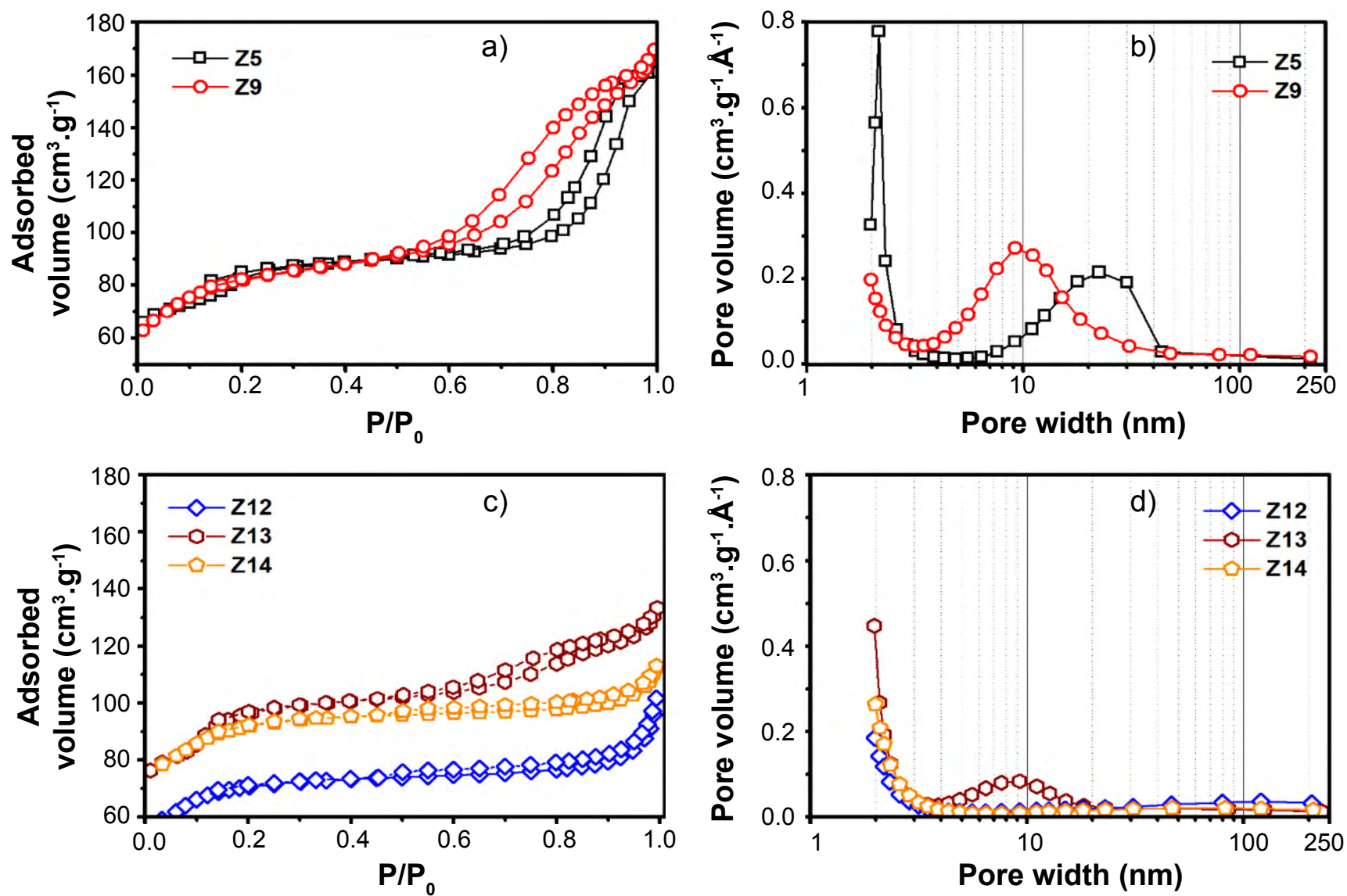

Figure 4: $\mathrm{N}_{2}$ adsorption-desorption isotherms (a,c) and pore size distribution profiles obtained by the BJH method (b, d) of the relevant ZSM-5 samples.

[Figura 4: Isotermas de adsorção-dessorção de $N_{2}(a, c)$ e perfis de distribuição de tamanho de poros obtido pelo método BJH (b, d) das amostras de ZSM-5 relevantes.]

Table V - Textural properties obtained by adsorption of $\mathrm{N}_{2}$ and acidity measurements determined by $\mathrm{NH}_{3}$-TPD.

[Tabela $\mathrm{V}$ - Propriedades texturais obtidas por adsorção de $\mathrm{N}_{2}$ e medidas de acidez determinadas por TPD-NH${ }_{3}$.]

\begin{tabular}{ccccccccccc}
\hline Sample & $\begin{array}{c}\mathrm{S}_{\mathrm{BET}}{ }^{\mathrm{a}} \\
\left(\mathrm{m}^{2} \cdot \mathrm{g}^{-1}\right)\end{array}$ & $\begin{array}{c}\mathrm{S}_{\mathrm{E}}^{\mathrm{b}} \\
\left(\mathrm{m}^{2} \cdot \mathrm{g}^{-1}\right)\end{array}$ & $\begin{array}{c}\mathrm{S}_{\mathrm{Mic}}{ }^{\mathrm{c}} \\
\left(\mathrm{m}^{2} \cdot \mathrm{g}^{-1}\right)\end{array}$ & $\begin{array}{c}\mathrm{V}_{\mathrm{T}}^{\mathrm{d}} \\
\left(\mathrm{cm}^{3} \cdot \mathrm{g}^{-1}\right)\end{array}$ & $\begin{array}{c}\mathrm{V}_{\mathrm{Mic}}{ }^{\mathrm{e}} \\
\left(\mathrm{cm}^{3} \cdot \mathrm{g}^{-1}\right)\end{array}$ & $\begin{array}{c}\mathrm{D}^{\mathrm{f}} \\
(\mathrm{nm})\end{array}$ & $\mathrm{HF}^{\mathrm{g}}$ & \multicolumn{2}{c}{$\begin{array}{c}\text { Acid amount } \\
\left(\mu \mathrm{mol}_{\mathrm{g}}{ }^{-1}\right)\end{array}$} & $\mathrm{S} / \mathrm{W} \mathrm{ratio}^{\mathrm{h}}$ \\
$\mathrm{Z} 5$ & 285 & 187 & 98 & 0.25 & 0.04 & 6.3 & 0.10 & 179 & 102 & 0.57 \\
$\mathrm{Z} 9$ & 285 & 126 & 158 & 0.25 & 0.07 & 7.5 & 0.12 & 234 & 118 & 0.50 \\
$\mathrm{Z} 12$ & 244 & 98 & 145 & 0.14 & 0.07 & 6.8 & 0.20 & 235 & 122 & 0.52 \\
$\mathrm{Z} 13$ & 340 & 205 & 135 & 0.20 & 0.06 & 4.7 & 0.18 & 225 & 132 & 0.59 \\
\hline
\end{tabular}

${ }^{a}$ BET surface area; ${ }^{b}$ External surface area; ${ }^{c}$ Micropore surface area; ${ }^{d}$ Total pore volume at $P / P_{0}=0.97 ;{ }^{e}$ Micropore volume, $S_{\text {mic }}, S_{E}, V_{\text {mic }}$ by $t$-plot method; ${ }^{f}$ Mean pore width by BJH method; ${ }^{g}$ Hierarchy factor $=\left(V_{M i c} / V_{T}\right) \cdot\left(S_{E} / S_{B E T}\right) ;{ }^{h} W$-weak, $S$-strong, $S / W$-strong/weak ratio.

ratios, indicating a less efficient ethanol template effect when compared to $\mathrm{TPA}^{+}$cations. Conversely, based on the possibility of retaining positive charges, organic amines are better-directing agents when compared to ethanol, because they easily form complexes through $\mathrm{H}$ bonds of the $\mathrm{Si}-\mathrm{OH}$ terminal groups of the silicate anion [27], thus requiring a lower $\mathrm{SDA} / \mathrm{SiO}_{2}$ ratio.

The micrographs of the ZSM-5 catalysts that were prepared using different compositions are shown in Fig. 5.
The samples synthesized under static conditions exhibited crystals characteristic of the MFI phase, with hexagonal and spherical morphologies with different sizes [27, 42]. The magadiite phase can be observed as lamella-like structures stacked in the same direction $[36,38]$. The uniform size of the crystals of zeolite can be attributed to the addition of seeds to the gel, which induced the fast crystallization of zeolite [43]. In another study [44], the materials formed presented a large cluster of crystalline faces that are inherent 

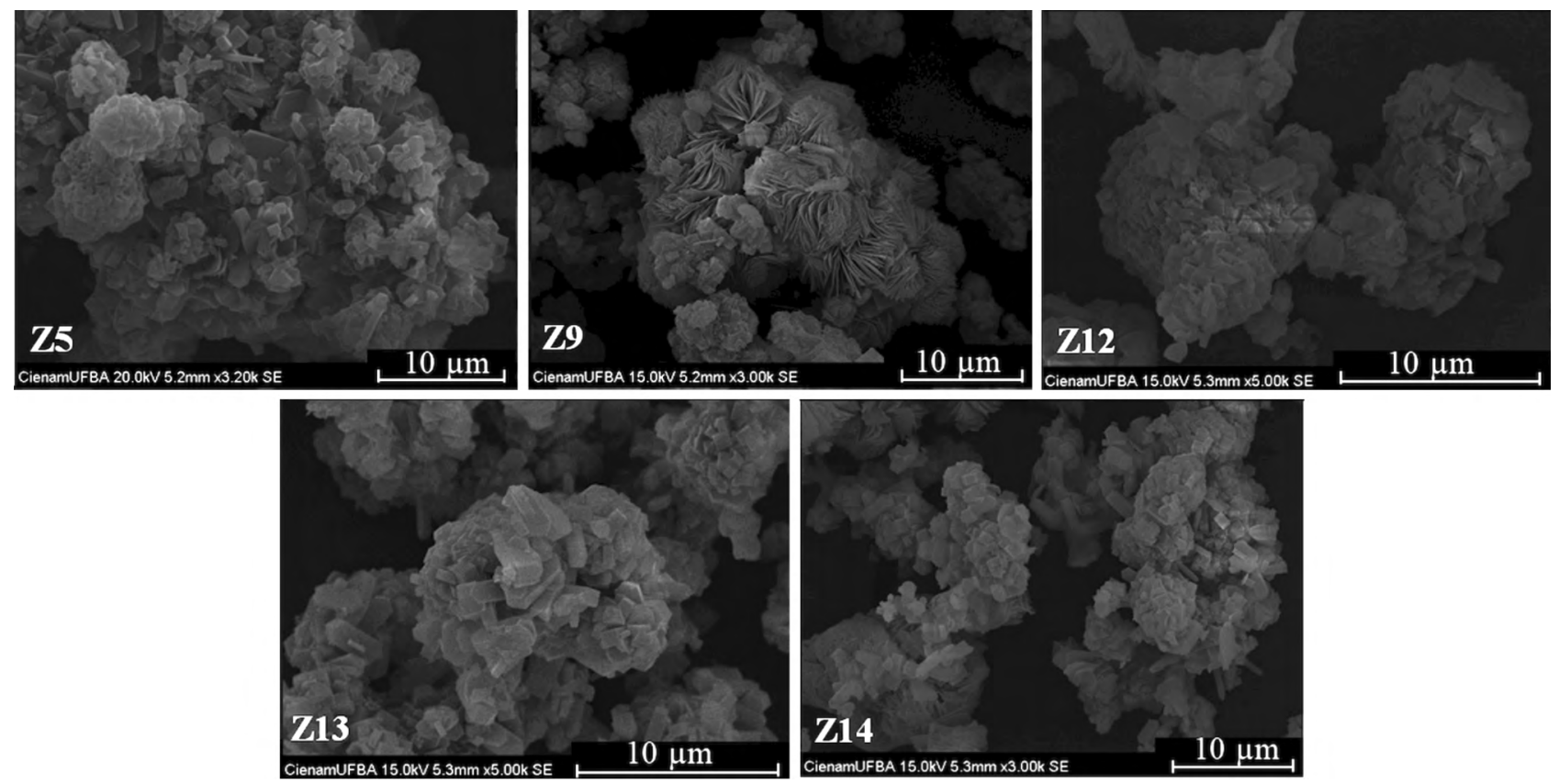

Figure 5: SEM micrographs of the ZSM-5 materials with different magnifications.

[Figura 5: Micrografias de MEV dos materiais de ZSM-5 com diferentes ampliações.]
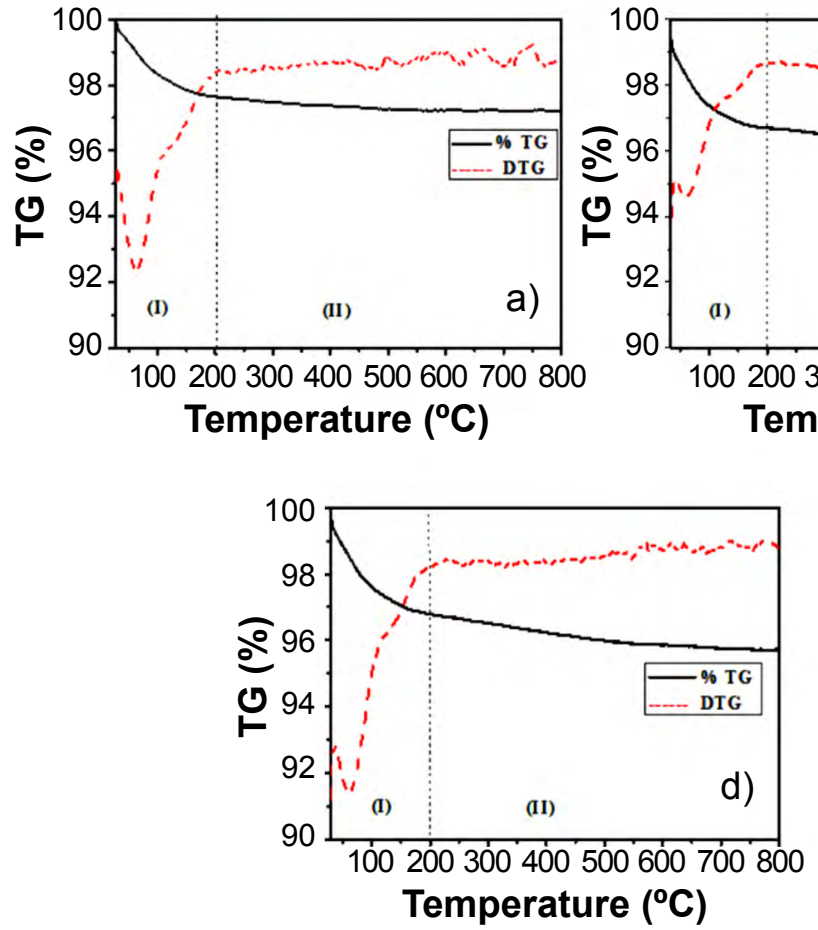
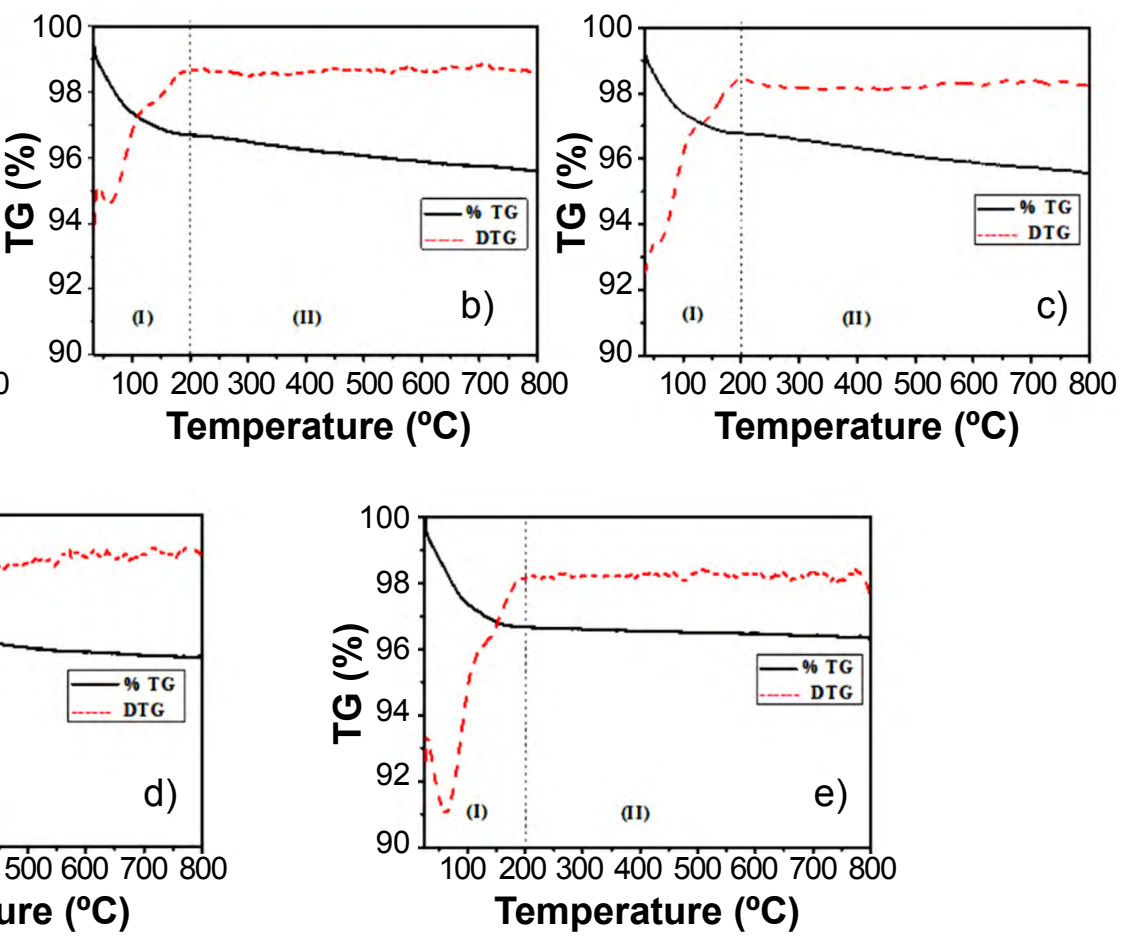

Figure 6: TG/DTG curves of samples: a) Z5; b) Z9; c) Z12; d) Z13; and e) Z14.

[Figura 6: Curvas de TG/DTG das amostras: a) Z5; b) Z9; c) Z12; d) Z13; e e) Z14.]

to the crystallization process with the addition of seeds to the reaction medium. It was concluded that the crystalline intergrowth was due to the conditions of the medium formed by the precursors together with the multinucleation provided by the insertion of the seed crystals, causing the nucleation and growth of these particles on the surfaces of the crystals already formed. Several studies [41, 43, 45] have reported that size, hydrophobicity and geometric shape of the structure-directing agent affect the form of filling and growth of the crystals, thus, various orientations and crystal morphologies are achieved. The crystal size is also related to the SAR used in the gel, although the aggregation of the crystals was favored by the presence of aluminum [40].

In order to better understand the removal of molecules 


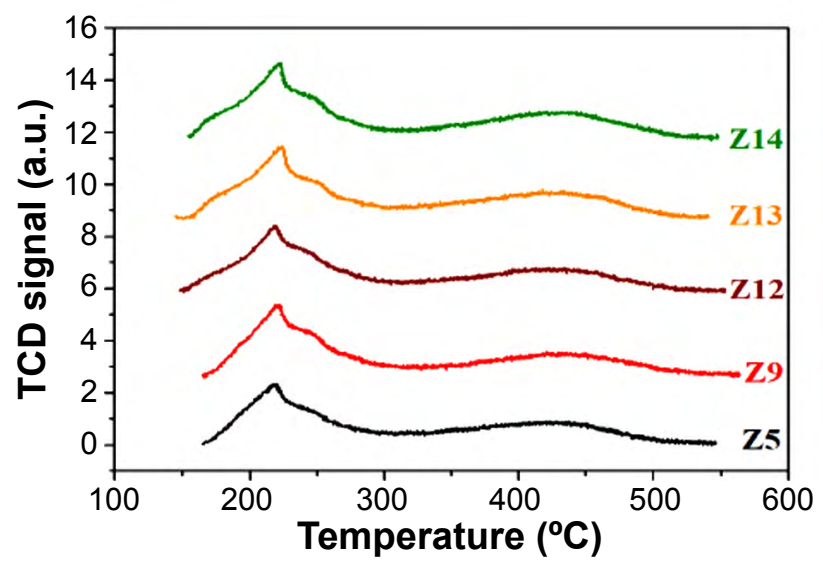

Figure 7: $\mathrm{NH}_{3}$-TPD profiles of HZSM-5 samples.

[Figura 7: Perfis de TPD-NH $\mathrm{N}_{3}$ das amostras de HZSM-5.]

inside the pores of ZSM-5 zeolites, such as physically adsorbed water and SDA's, thermogravimetric analyses of the samples were performed (Fig. 6). The synthesized samples present two stages of mass loss. The first one showed the loss of continuous mass in the range of 25 to $200{ }^{\circ} \mathrm{C}$, related to the dehydration of the physically adsorbed water in the porous of the MFI [46]. The second step, in the range of 200 to $800^{\circ} \mathrm{C}$, may be related to the decomposition of SDA [26] and to the desorption of ammonia molecules resulting from the ammonium ion decomposition since the commercial ZSM-5 in its ammoniacal form was used as seed. A similar observation was made in [47].

Acidity of samples: the quantity and acid strength of the ZSM-5 samples were measured by $\mathrm{NH}_{3}$-TPD. As shown in Fig. 7, all samples showed two major desorption peaks in the $150-300$ and $300-550{ }^{\circ} \mathrm{C}$ regions, which were attributed to chemical adsorption of ammonia at weak and strong acid sites, respectively [48, 49]. In other studies [50-52] the ZSM-5 was analyzed by the $\mathrm{NH}_{3}$-TPD technique, where the first peak was assigned to weakly adsorbed molecules at the outer surface sites. However, it might also have been due to the interaction of $\mathrm{NH}_{3}$ molecules with surface oxides or, another explanation could be hydroxyl groups by nonspecific hydrogen bonds or foreign material. The second peak was attributed to chemosorbed $\mathrm{NH}_{3}$ molecules. These two peaks corresponded to the bands in the infrared (3550$3740 \mathrm{~cm}^{-1}$ ) of hydroxyl groups related to surface acidity of these materials. Several authors $[24,53]$ report that the number of total acid sites of the zeolites decrease with the increase of the $\mathrm{SiO}_{2} / \mathrm{Al}_{2} \mathrm{O}_{3}$ ratio, and it is expected that the $\mathrm{Z} 9$ sample should have the highest number of acid sites due to its lower $\mathrm{SiO}_{2} / \mathrm{Al}_{2} \mathrm{O}_{3}$ ratio, while the $\mathrm{Z12}$ sample would have a lower number of acid sites due to higher $\mathrm{SiO}_{2} / \mathrm{Al}_{2} \mathrm{O}_{3}$ ratio, however this was not observed (Table III). Well-crystallized MFI structures have predominantly tetrahedral $\mathrm{Al}$ atoms coordinated in the structure (>95\%) [54], and there are other factors besides the $\mathrm{SiO}_{2} / \mathrm{Al}_{2} \mathrm{O}_{3}$ ratio, such as the difference in the composition of the synthesis gels that lead to possible different distributions of $\mathrm{Al}$ atoms in the structure, reflecting on a different acidity in the ZSM-5 samples [55]. Although all the synthesis started from the same $\mathrm{SiO}_{2} / \mathrm{Al}_{2} \mathrm{O}_{3}$ ratio,
Table VI - Conversion, coke content, and distribution of products for the cracking of n-hexane.

[Tabela VI - Conversão, teor de coque formado e distribuição de produtos para o craqueamento do n-hexano.]

\begin{tabular}{cccccc}
\hline $\begin{array}{c}\text { Cracking } \\
\text { product }\end{array}$ & Z5 & Z9 & Z12 & Z13 & Z14 \\
\hline $\begin{array}{c}\text { Conversion } \\
(\%)\end{array}$ & 45 & 73 & 64 & 67 & 65 \\
$\begin{array}{c}\text { a } \\
\text { Coke content }\end{array}$ & 1.4 & 1.9 & 2.6 & 4.0 & 3.0 \\
$(\%)$ & & & & & \\
$\begin{array}{c}\text { Distribution of } \\
\text { products (wt\%) }\end{array}$ & & & & & \\
Methane & 2 & 3 & 3 & 3 & 2 \\
Ethane & 10 & 9 & 9 & 9 & 10 \\
Ethene & 12 & 16 & 15 & 16 & 15 \\
Propane & 16 & 18 & 18 & 18 & 18 \\
Propene & 35 & 29 & 29 & 29 & 31 \\
$\geq C 4$ & 25 & 25 & 29 & 25 & 26 \\
Total (\%) & 100 & 100 & 100 & 100 & 100 \\
\hline
\end{tabular}

${ }^{a}$ Values after 121 min of reaction; ${ }^{b}$ Values by $T G$ analyses: range $800-1000{ }^{\circ} \mathrm{C}$, samples after the reaction.

the acidity difference can be caused by the nature of the SDA, resulting in the formation of $\mathrm{Al}$ extra lattice species (EXFAL), which have a low ammonia adsorption capacity compared to the structural $\mathrm{Al}$ species (FAL).

Catalytic properties: the performance and distribution of the catalytic cracking products of $n$-hexane under the HZSM-5 zeolites are listed in Table VI. All samples were effective in the n-hexane cracking reaction. The Z9 sample, synthesized with propylamine with ratios $\mathrm{SDA} / \mathrm{SiO}_{2}=0.1$ and $\mathrm{OH} / \mathrm{SiO}_{2}=0.2$, presented the highest activity, despite not showing strong acidity when compared to the other samples, according to $\mathrm{NH}_{3}$-TPD results. It has been described that in the cracking of $\mathrm{n}$-hexane, the most important is the number of strong acid sites and not the acidic force [55]. It has already been shown that the catalytic activity for the cracking of $\mathrm{n}$-hexane is proportional to the aluminum structure [56]. However, in our tests, the results of the conversion did not show that. The greater activity demonstrated by the Z9 sample may be due to better accessibility of the reagents to the acid sites. It has been reported that accessibility to acid sites is the main factor that influences catalytic activity, rather than acidic force [57]. The coexistence of structural aluminum intra and extra lattice in the sample Z9 may be the reason for higher activity [58-60]. The product distributions are shown in Table VI, where all samples exhibited preferential selectivity in the following order propene>propane $>$ ethene $>$ ethane.

\section{CONCLUSIONS}

The methodology of introducing seed crystals together with an alternative structure-directing agent developed in 
this study revealed a process where ZSM-5 with high-silica contents can be synthesized according to the parameters adopted. The increase of the $\mathrm{OH} / \mathrm{SiO}_{2}$ and $\mathrm{SDA} / \mathrm{SiO}_{2}$ ratios favored the formation of the lamellar magadiite phase, and when the system was agitated, the concurrent phase cristobalite was observed in the X-ray diffraction profiles. It was observed that these products occur in reaction mixtures with high $\mathrm{SiO}_{2} / \mathrm{Al}_{2} \mathrm{O}_{3}$ ratios. The addition of ethanol was less efficient since the results indicated that this compound was partially incorporated in the lattice, thus requiring a larger amount to achieve a significant effect. In contrast, the addition of propylamine directed the crystallization of the material in $18 \mathrm{~h}$ of hydrothermal crystallization. The catalytic test indicated that the $\mathrm{SiO}_{2} / \mathrm{Al}_{2} \mathrm{O}_{3}$ ratio interfered in the performance of the catalyst, which was directly linked to the strength and concentration of the acid sites of the material.

\section{ACKNOWLEDGMENTS}

The authors acknowledge CAPES, CNPq and PETROBRAS for their financial support and TECNANO of the Federal University of Alagoas for analyzes of energy dispersive X-ray spectroscopy, and the CIENAM of the Federal University of Bahia for scanning electron microscopy analyzes.

\section{REFERENCES}

[1] O.A. Fouad, R.M. Mohamed, M.S. Hassan, I.A. Ibrahim, Catal. Today 116 (2006) 82.

[2] G.T. Kokotailo, S.L. Lawton, D.H. Olson, Nature 272 (1978) 437.

[3] D.H. Olson, G.T. Kokotailo, S.L. Lawton, J. Phys. Chem. 85 (1981) 2238.

[4] G. Kesicka, J. Perkcwski, Przem. Chem. 60 (1981) 516.

[5] Z. Song, W. Liu, C. Chen, A. Takahashi, T. Fujitani, React. Kinet. Mech. Catal. 109 (2013) 221.

[6] Y. Furumoto, Y. Harada, N. Tsunoji, A. Takahashi, T. Fujitani, Y. Ide, M. Sadakane, T. Sano, Appl. Catal. A Gen. 399 (2011) 262.

[7] R.J. Argauer, G.R. Landolt, U.S. 3702886 (1972).

[8] B.M. Lok, T.R. Cannan, C.A. Messina, Zeolites 3 (1983) 282.

[9] Mobil Oil Corp, GB1471440A (1977).

[10] M.K. Rubin, E.J. Rosinski, C.J. Plank, U.S. 4151189 (1979).

[11] C.J. Plank, E.J. Rosinski, M.K. Rubin, U.S. 4046859 (1977).

[12] L.D. Rollmann, W.E. Valyocsik, U.S. 4139600 (1979).

[13] S. African Appl. 787037 (1978).

[14] Idenitsu Kosan Co., JPO 8207816 (1982).

[15] H. Hagiwara, Y. Kiyozumi, M. Kurita, T. Sato, H. Simada, K. Suzuki, S. Shin, A. Nishijima, N. Todo, Chem. Lett. (1981) 1653.

[16] Shell Int. Res. Mij BV, GB 2018232 (1979).

[17] Y.L. Lam, L. Nogueira, S.C. Fernandez, BR PI8606367
(1988).

[18] Y.L. Lam, BR PI8506248 (1987).

[19] Q. Yu, X. Meng, J. Liu, C. Li, Q. Cui, Microporous Mesoporous Mater. 181 (2013) 192.

[20] G. Wu, W. Wu, X. Wang, W. Zan, W. Wang, C. Li, Microporous Mesoporous Mater. 180 (2013) 187.

[21] T. Xue, Y.M. Wang, M. He, Solid State Sci. 14 (2012) 409.

[22] T.R.D. Mendonça, "Synthesis of ZSM-5 zeolite with addition of seeds using different silicon sources", M.Sc. Diss., Fed. Un. Alagoas, Maceió (2013).

[23] B.M. Lowe, J.R.D. Nee, J.L. Casi, Zeolites 14 (1994) 610.

[24] G. Wu, W. Wu, X. Wang, W. Zan, W. Wang, C. Li, Microporous and Mesoporous Mater. 180 (2013) 187.

[25] S. Narayanan, A. Sultana, Q.T. Le, A. Auroux. Appl. Catal. A Gen. 168 (1998) 373.

[26] M.K. Naskar, D. Kundu, M. Chatterjee, J. Am. Ceram. Soc. 95, 2 (2012) 449.

[27] S. Sang, F. Chang, Z. Liu, C. He, Y. He, L. Xu, Catal Today 93-95 (2004) 729.

[28] D5758-01, "Standard test method for determination of relative crystallinity of zeolite ZSM-5 by X-ray diffraction", ASTM Int., West Conshohocken (2015).

[29] J.R. Anderson, K.C. Pratt, Introduction to characterization and testing of catalysts, Acad. Press, Sydney (1985) 67.

[30] J.A. Martens, P.A. Jacobs, Stud. Surf. Sci. Catal. 33 (1987) 113.

[31] B. Xu, X. Zhu, Z. Cao, L. Yang, W. Yang, Chin. J. Catal. 36 (2015) 1060.

[32] D.L. Guerra, A.A. Pinto, J.A. de Souza, C. Airoldi, R.R. Viana, J. Hazard. Mater. 166 (2009) 1550.

[33] S.J. Kim, M.H. Kim, Y. Ko, G. Seo, Y.S. Uh, Stud. Surf. Sci. Catal. 135 (2001) 234.

[34] K.W. Park, J.H. Jung, H.J. Seo, O.Y. Kwon, Microporous Mesoporous Mater. 121 (2009) 219.

[35] K. Ozawa, R. Okada, Y. Nakao, T. Ogiwara, H. Itoh, F. Iso, J. Am. Ceram. Soc. 93 (2010) 4022.

[36] Y. Liu, Z. Wang, Y. Ling, X. Li, Y. Liu, P. Wu, Chin. J. Catal. 30 (2009) 525.

[37] I.A. Bakare, O. Muraza, S.A. Ganiyu, A.S. Hakeem, Z.H. Yamani, A.M.J. Al-Amer, Particuology 27 (2016) 34.

[38] S.P. Zhdanov, N.N. Feoktistova, N.I. Kozlova, I.G. Polyakova, Inorg. Chem. 34, 12 (1985) 2463.

[39] M. Cui, Y. Mu, S. Zhang, L. Wang, C. Meng, Microporous Mesoporous Mater. 265 (2018) 63.

[40] M. Razavian, S. Fatemi, Mater. Chem. Phys. 165 (2015) 55.

[41] M.A. Uguina, A. Lucas, F. Ruiz, D.P. Serrano. Ind. Eng. Chem. Res. 34, 2 (1995) 451.

[42] F. Yaripour, Z. Shariatinia, S. Sahebdelfar, A. Irandoukht, J. Nat. Gas Sci. Eng. 22 (2015) 260.

[43] M.B. Yue, N. Yang, W.Q. Jiao, Y.M. Wang, M. He, Solid State Sci. 20 (2013) 1.

[44] J. Warzywoda, R.D.Edelman, R.W. Thompson, Zeolites 11 (1991) 318. 
[45] N.L. Chauhan, J. Das, R.V. Jasra, P.A. Parikh, Z.V.P. Murthy, Mater. Lett. 74 (2012) 115.

[46] O.G. Somani, A.L. Choudhari, B.S. Rao, S.P. Mirajkar, Mater. Chem. Phys. 82 (2003) 538.

[47] A.N. Kotasthane, V.P. Shiralkar, Thermochim. Acta 102 (1986) 31.

[48] B.M. Lok, B.K. Marcus, C.L. Angell, Zeolites 6 (1986) 185.

[49] K.-P. Wendlandt, H. Toufar, B. Unger, W. Schwieger, K.-H. Bergk, J. Chem. Soc. Faraday Trans. 87, 15 (1991) 2507.

[50] J.R. Anderson, K. Foger, T. Mole, R.A. Rajadhyaksha, J.V. Sanders, J. Catal. 58 (1979) 114.

[51] N. Topsoe, K. Pedersen, E.G. Derouane, J. Catal. 70 (1981) 41.

[52] G.P. Babu, S.G. Hegde, S.B. Kulkarni, P. Ratnasamy, J. Catal. 81 (1983) 471.

[53] C. Costa, I.P. Dzikh, J.M. Lopes, F. Lemos, F.R. Ribeiro,
J. Mol. Catal. A Chem. 154 (2000) 193.

[54] J. Dedecek, V. Balgová, V. Pashkova, P. Klein, B. Wichterlová, Chem. Mater. 24 (2012) 3231.

[55] J.G. Post, J.H.C. van Hooff, Zeolites 4 (1984) 9.

[56] J.M. Francisco, M.L. Carmen, A.C. María, C. Urbina, Appl. Catal. A Gen. 181 (1999) 29.

[57] T. Masuda, Y. Fujikata, S. Mukai, K. Hashimoto, Appl. Catal. A Gen. 172 (1998) 73.

[58] A. Ashton, S. Batmanian, D. Clark, J. Dwyer, F. Fitch, A. Hinhcliffe, F.J. Machado, Stud. Surf. Sci. Catal. 20 (1985) 101.

[59] R.M. Lago, W.O. Haag, R.J. Mikovsky, D.H. Olson, S.D. Hellring, K.D. Schmitt, G.T. Kerr, Stud. Surf. Sci. Catal. 28 (1986) 677.

[60] V.L. Zholobenko, L.M. Kustov, V.B. Kasansky, E. Loeffler, U. Lohser, Ch. Peuker, G. Oehlmann, Zeolites 10 (1990) 30.

(Rec.09/12/2018, Rev. 15/01/2019, Ac. 14/02/2019) 